\title{
Research on College English Teaching Model Reform Based on E-portfolio
}

\author{
Zhang Jin $^{1}$ \\ Foreign Language dept \\ Wuhan Donghu University \\ Wuhan, China \\ 315854976@qq.com
}

\author{
Wang Chunge ${ }^{2}$ \\ Foreign Language dept \\ Wuhan Donghu University \\ Wuhan, China \\ 760019367@qq.com
}

\begin{abstract}
With the further development of the information technology and extensive application of E-portfolios in college English teaching, the traditional college English teaching model is confronted with new challenges. Directing at the insufficiency of traditional college English teaching model, this essay discusses target, content, significance of informatizationized college English teaching model reform based on application of E-portfolios.
\end{abstract}

Key words: E-portfolio; College English; informationized teaching;

\section{Research Background}

With the development and penetration of information technology, new education ideas and modes being put forward, E-portfolios start to get applications and popularization in college English learning. This not only impels the previous passive learning into active learning, but also proposes challenge to the traditional college English teaching mode. Based on the application of E-portfolios in college English teaching and learning, how to reform, design effective college English teaching mode, and to make a scientific and reasonable assessment, is the important theoretical and practical problem urgently needed to be solved during E-portfolios' application research.

\section{Review of Traditional Informationized College English Teaching Mode}

E-portfolios' application in college English emerges and is based on the shortcomings of the traditional informationized college English teaching mode. It is not the complete negation to the traditional informationized college English teaching mode, but supplement and perfection for it. At the same time it is also challenge of modern information technology to the traditional college English teaching concept, teaching method, teaching content and teaching evaluation in the new condition of information technology. The traditional informationized

college English teaching mode shows the teaching content mainly through pictures, words, sound and images with the aid of computer and multimedia. Through the use of computer and multimedia as a teaching method, it greatly improves the efficiency of English teaching, makes the teaching content more intuitive and more vivid, enhances students' understanding of the teaching content, reduces the students' learning burden and improves the learning efficiency. Through some films and television work, it improves the students' English vocabulary and grammar understanding, exercises the students' oral English, activates English classroom atmosphere, thus aroused the students' interest in and enthusiasm for English learning, therefore improves the English classroom teaching effect and quality, liberates English teachers from a large amount of hard and repeated physical labor in class before mainly in oral lecture with chalk writing as complementary, consequently guarantees more time for teaching exploration and researching. In general, the traditional informationized college English teaching mode enhances the efficiency of teaching and learning, and improves teaching quality and effect. However, with the further development of the modern information technology, teaching means come to be more and more intelligent and webified. In the course of English learning, as learners students' learning subjectivity has been enhanced, the traditional informationized college English teaching mode is difficult to adapt to the new form of teaching requirements. This is mainly because the traditional mode has not been adjusted to the rapid development of information technology, and it mainly shows in the following aspects:

First, the information source of traditional informationized college English teaching mode does not change fundamentally. In the traditional model, the teacher and the teaching material is still the main information source, and neglected the students is also important main body of information source. Informationized College English teaching, compared with the noninformationized teaching method, is just reliance on chalk and books turning to dependence on computer and multimedia, the students' subjective position learning was not truly reflected, the information transfer is just a change from "person" sending to "machine" sending. As a kind of language learning, English learning is not only dependent on teacher's explanation and books, learners can achieve active learning through various forms such as discussion in English, mutual evaluation on English writing and translation, etc.. And this is precisely what the traditional informationized English teaching mode has neglected.

Second, the traditional informationized college English teaching mode was greatly limited by time and space, and relies heavily on classroom. Rapid technical development of the network in modern society breaks the limit on time and space in the English learning process and improves the efficiency of information transfer and 
learning. At the same time, students of English learning do not necessarily depend on class and teachers. As a kind of language learning, English requires more usage in life, and separation from class limit on time and space into lively circumstances, while the traditional mode focuses on classroom teaching, in which English learning did not extend beyond time and space limit.

Third, the traditional teaching mode focuses on the learning needs of majority students, and difficult to meet students' personalized and diversified demands. Integrated teaching contents and single teaching means, lead to lack of personalized teaching information, and difficult to stimulate students' active learning enthusiasm or improvement of learning efficiency.

Directing at the above three aspects of insufficiency of traditional informationized college English teaching models, E-portfolios' wide application and promotion in learning and teaching overseas is a successful attempt of teaching reform under the new information condition. A large number of foreign successful application of E-portfolios shows that it is a helpful tool to realization of students' autonomous learning and improve the traditional instruction. E-portfolios' application is thus the inevitable result in the process of reform of traditional informationized college English teaching in this new situation.

\section{College English Teaching Model Reform Based on E-portfolio}

1. Content of Informationized College English Teaching Mode Reform Based on E-portfolios

English E-portfolios mainly use appropriate technology to serve learning, based on computer simulation and "micro world" application of E-portfolios, design teaching modules of college English reading, writing, listening, speaking and translation that integrates knowledge, interest, enthusiasm and learning, wherefrom realizes customization learning, peer assisting learning, self-directed learning, and technology assisted learning, hence achieves teaching system to take the students as the center and not the teaching as the center. Through the application of knowledge module design in teaching, it stimulates interest in learning and achieves more effective learning, which shows specifically in:

First of all, under the condition of informationization, based on the application of E-portfolios in college English learning and teaching, this paper analyzes its applicability to traditional informationized college English teaching mode. Aimed at some shortage in the traditional mode, design and construct teaching modules of reading, writing, listening, speaking, translation and teaching outline of college English which adapts to E-portfolios, and then choose students of different grades and majors as the object for concrete implementation.

Secondly, build the evaluation index, and develop evaluation on the effect of newly designed informationized teaching mode which adapts to E-portfolios, including college English reading, writing, listening, speaking and translation teaching module, teaching outline, etc. And according to the result of the evaluatation make further improvement and optimization of the design of teaching module and teaching outline of college English reading, writing, listening, speaking and translation.

\section{Target of Informationized College English Teaching Mode Reform Based on E-portfolios}

First, based on the application of E-portfolios in foreign language learning, draw on the experience of foreign language knowledge module design overseas, combined with our country's college English learners' level and discipline background, construct and design college English teaching module and teaching outline of reading, writing, listening, speaking, translation adapting to E-portfolios, and enrich knowledge base of college English autonomous learning. To provide "maintenance" for college English learning, promote formation of students' individual learning method and development of students' autonomous learning ability; make students from passive learning become active learning, and the transformation of teaching focus from "teaching" to "learning". Reflect combination of principles of practicality, informativity and interest in English teaching, in order to arouse both aspects of teachers' and students' enthusiasm, especially to reflect the subject status of students and teachers' leading role in the teaching process.

Second, to explore building informationized college English teaching mode supported by E-portfolios, thus fundamentally change the traditional classroom language teaching mode based on computer and network, improve the single teaching mode of teachers' teaching as primary. To provide learning conditions of personalization and socialization for new generation of learners, make English teaching and learning not affected by time or place limit to a certain extent, develop in the direction of personalized and autonomous learning, and effectively support the informationized college English teaching.

Third, construct teaching mode adapting to modern network information technology, and suitable for students' personalized and diversified learning needs, realize information sharing among the students, complementary to the traditional informationized teaching mode. Based on the application of E-portfolios, this informationized college English teaching mode, better make up for the insufficiency of traditional college English teaching mode, meet the learning needs of the new generation of learners' in English break and outside classroom under modern network environment, help mutual promotion between learners, build English learning environment beyond time and space limit, change the teaching mode of teacher as the only information source, and make students mutually promote English learning ability.

\section{Significance of Informationized College English} Teaching Mode Reform Based on E-portfolios

(1) Based on the application of E-portfolios in college English study, through the design of teaching modules of 
college English reading, writing, listening, speaking and translation adapting to E-portfolios, reach the sharing, building, and reflection, evaluation in foreign language study, provide conditions for application of E-portfolios in college English learning. Thus realizes the transformation from the teaching thought and practice of teacher as the center who purely teaches language knowledge and skills, to take the student as the center, not only language knowledge and skills are taught, but more attention to the cultivation of language application ability and the competence of autonomous learning, also a change to cultivate students' lifelong learning ability oriented to lifelong education. In practice, it can create favorable conditions for application of E-portfolios in college English learning, help English learners improve learning efficiency, and enhance teaching quality of college English, as well as popularization of E-portfolios in college English teaching and learning in our country. At the same time, also provide reference for application of E-portfolios in other courses as well as their informationized teaching mode reform.

(2) Design effective reading, writing, listening, speaking, translation teaching modules, and through interactive share guide the students to learn actively, thus realize the diversification of foreign language learning. Polymerization of good learning results and teaching modules, allows others to share and browse works online. To realize effective sharing and cooperation among students, teachers, parents and regulators, and consequently improve the quality of teaching and learning efficiency. Based on the application of E-portfolios, informationized college English teaching mode covers the whole process of teaching, learning, feedback, and management systematically, including the students' learning and self-evaluation, teachers' teaching, teachers' online tutoring, and monitoring management on the students' learning and teachers' guidance, that it can record, understand, test students' learning and teachers' teaching and guidance at any time, thereby reflect social, interactive and multimedia characteristics, as well as effectively support informationized college English teaching.

\section{Acknowledgement}

Government-funded program:Research on College English Teaching Model Reform Based on E-portfolio-2012 Hubei Provincial Department of Education Teaching \& Research Project (English Specific)

\section{Conferences}

[1] Wang Youmei, Informationized College English Teaching Framework and Application Supported by Interactive E-portfolios [J]. China Information Times. 2010.12

[2] Duan Guining. Recent Domestic Research on E-portfolios and Analysis of Its Current Application [J]. Journal of Chongqing RTV University. 2008.3

[3] Wang Youmei, E-portfolios: New Ideas of Informationized Teaching

[J]. China Educational Technology. 2002.10
[4] Chen Hongyi,etc..Effectiveness Principle of College Network Teaching and Evaluation [J].China Education Info.2007.9

[5] Luo Hongwei, etc.. Research on Lack of Emotion in Network Learning Environment [J] Open Education Research.2008.3 